\title{
Sikap Ekslusivisme Masyarakat Tionghoa Tangerang terhadap Penguasaan Ekonomi Pasar
}

\author{
Lisda Triana1*, Aulia Ulfa Utami2, Muhamad Abi Fadila ${ }^{3}$, Azzumar Abdillah \\ Husien $^{4}$, Sulaeman ${ }^{5}$
}

1,2,3,4,5 Universitas Muhammadiyah Prof. Dr. Hamka, Indonesia

\section{ART ICLE INF O \\ Article history: \\ Received July 16, 2021 \\ Revised July 20, 2021 \\ Accepted September 15, 2021 \\ Available online October 25, 2021 \\ Kata Kunci: \\ Sikap Ekslusivisme, Tionghoa, Ekonomi \\ Pasar \\ Keywords: \\ Exclusivism, Chinese, Market Economy

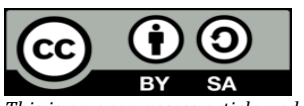 \\ This is an open access article under the $\underline{C C B Y-S A}$ license. \\ Copyright (C) 2021 by Author. Published by Universitas Pendidikan Ganesha.}

\begin{abstract}
A B S T R A K
Di Indonesia kegiatan usaha kecil menengah didominasi oleh masyarakat Tionghoa yang memiliki peran dalam perekonomian. Penelitian ini bertujuan untuk menganalisis sikap ekslusivisme masyarakat tionghoa terhadap penguasaan ekonomi pasar. Metode penelitian yang digunakan dalam penelitian ini yaitu dengan menggunakan metode penelitian kualitatif, penelitian ini didalamnya melakukan observasi langsung ke lapangan, dan pendekatan fenomenologi. Hasil penelitian ini yaitu ajaran konfusianisme merupakan ajaran konfusius berupa etika dan moral yang saling berhubungan antar manusia mengandung unsurunsur sifat bijak manusia yang berpedoman pada sifat yang terpuji, jika ada kekacauan di masyarakat dapat diatasi. Kedatangan etnis tionghoa ke nusantara belum ada gambaran yang jelas tetapi sudah lama sebelum jayakarta dikuasi oleh belanda di bawah pimpinan Jan Pieterszoon Coen pada tahun 1619. Pemahaman mereka terhadap kofusianisme tidak terlalu mengenal ajaran yang diajarkan kofusius, namun secara tidak sadar perilaku berdagang etnis Tionghoa sebagian mencerminkan ajaran konfusius, tidak terlalu ambisius, sederhana dan tetap meghargai usaha yang dikerjakan dengan menjaga kualitas barang.
\end{abstract}

\section{A B S T R A C T}

In Indonesia, the activities of small and medium enterprises are dominated by the Chinese community who have a role in the economy. This study aims to analyze the exclusivism attitude of the Chinese community towards the domination of the market economy. The research method used in this study is to use qualitative research methods, this research includes direct observations to the field, and a phenomenological approach. The results of this study are that Confucianism is a Confucian teaching in the form of ethics and morals that are interconnected between humans containing elements of human wisdom based on commendable traits, if there is chaos in society it can be overcome. The arrival of ethnic Chinese to the archipelago is not yet clear, but it was a long time before Jayakarta was controlled by the Dutch under the leadership of Jan Pieterszoon Coen in 1619. Their understanding of Confucianism was not very familiar with the teachings taught by Confucius, but unconsciously the trading behavior of the ethnic Chinese partially reflected the teachings of Confucius, not too ambitious, simple and still appreciate the work done by maintaining the quality of the goods.

\section{PENDAHULUAN}

Indonesia merupakan negara dengan beragam suku bangsa dan bahasa, Indonesia secara luas dikenal sebagai negara yang bercorak multibudaya. Negeri ini terdiri dari ribuan suku bangsa yang tersebar di seluruh wilayahnya, memiliki ratusan dialek bahasa daerah, dan beragam jenis kesenian yang berbedabeda, serta memiliki kompleksitas kebudayaan yang sangat luar biasa banyaknya Masuknya, etnis Tionghoa ke Nusantara diperkirakan sudah ada tepatnya pada aba ke-4. Jumlah penduduk etnis ini sekitar 4-5\% dari penduduk Indonesia. Kedatangan etnis Tionghoa ke Nusantara juga memberikan konstribusi yang berarti dalam berbagai macam bidang, misalnya yaitu bidang perekonomian, bidang perekonomian yang sangat menonjol dari bidang lainnya, maka tidak heran jika etnis Tionghoa pandai berdagang, misalnya di pasarpasar, tidak sedikit etnis ini yang memilih berdagang di pasar, bahkan perdagangan mereka biasanya sangat ramai oleh pelanggan, karena etnis Tionghoa merupakan etnis yang sangat menghargai pekerjaan, hal tersebut masih mencerminkan bahwa etnis ini masih memakai ajaran konfusianisme (Wensi \& Azeharie, 2020; Yudha, 2020).

Namun, dinamika keberadaan etnis Tionghoa di Indonesia, tidak serta-merta memiliki kehidupan yang tentram dan damai, dalam perkembangannya di Indonesia. Terutama, pada sekitar tahun 1998, khususnya di bulan Mei, yang merupakan tragedi suram bagi etnis Tionghoa di Indonesia, dengan ingatan berupa tindak kekerasan bahkan psikologis, yang mereka alami dalam sejarah Indonesia (Kristiono, 2018, p. 35). Tetapi, masa-masa suram itu telah berlalu semenjak era reformasi, pada kepemimpinan presiden Gus Dur, etnis Tionghoa tampak mendapat angin segar dengan pengakuan agama Khonghucu. Melalui 
pengakuan agama Khonghucu tersebut, kini keberadaan etnis Tionghoa, sekiranya bukan lagi menjadi etnis yang terpinggirkan. Hal itu, juga karena mereka memegang teguh kepercayaan yang berkaitan dengan perubahan menjadi baik dari prinsip moral serta pendidikannya. Selain itu, etnis Tionghoa sudah membuktikan bahwa mereka dapat berkembang melalui keterampilan berwirausaha yang semestinya patut didukung oleh pemerintah (Syakur \& Faiq, 2020, pp. 259-260). Hal itu, diperkirakan dari 60\% hingga $70 \%$, pada bidang bisnis atau perdagangan banyak dikuasai oleh etnis Tionghoa, sementara jumlah etnis Tionghoa di Indonesia berjumlah 1-4,6\%. Jumlah tersebut, berbanding terbalik dengan jumlah masyarakat muslim untuk menyaingi para pengusaha dari etnis Tionghoa (Apria \& Mutia, 2018, p. 51). Sedangkan, etnis Tionghoa yang berada di Tangerang, atau Kota Lama Tangerang, yang sangat lekat dengan Pasar Lama, didekat pinggiran sungai Cisadane. Adalah, daerah yang tepat bagi keperluan sosial serta budaya (Prasetyo et al., 2017, p. 18). Demikian, penjelasan-penjelasan tersebut menerangkan kalau karakteristik dari aktivitas perekonomian yang dijalani etnis Tionghoa di Indonesia, sangat melekat dengan bidang bisnis atau perdagangan, bahkan bisa dikatakan sudah mendarah daging.

Sementara itu, berdasarkan pemaparan sebelumnya agaknya menarik bila aktivitas perekonomian etnis Tionghoa di Indonesia, bisa untuk dibandingkan dengan ajaran Konfusianisme. Dalam, bahasa mandarin ajaran Konfusianisme dikenal dengan sebutan Kongzi, yaitu ajaran dari Konfusius, seorang filsuf terkemuka dari China. Keteraturan dalam sebuah masyarakat merupakann suatu pandangan yang harus diciptakan oleh Konfusianisme. Konfusianisme ini, mengajarkan sebagaimana harusnya manusia menjadi bermoral, agar dapat memerintah dan mengatur masyarakatnya, dan memiliki sebuah sensitif akan kebutuhan sosial dan ekonominya (Hartati, 2016). Sementara, Konfusius seorang guru dan filsuf yang hidup pada 770-221 SM, hidup bertempat di negara bagian Lu atau kalau sekarang Provinsi Shandong, juga seorang intelektual yang menggemari budaya tradisional China yang berasal dari dinasti Zhou Barat yang terdapat pada waktu 150-770 SM (McArthur, 2019). Yang menandakan Konfusianisme merupakan falsafah kuno yang mendidik orang-orang China dalam memiliki moral yang luhur. Lalu, bagaimana dengan etnis Tionghoa di Indonesia? Jika, ditinjau dari historisnya pada masyarakat etnis Tionghoa tampak ajaran Konfusianisme masih diimplementasikan seperti contohnya, pada depresi ekonomi sekitar tahun 1930-an, yang dialami etnis Tionghoa di Palembang.

Untuk, menghadapi depresi ekonomi tersebut, etnis Tionghoa yang berada di Palembang khususnya di pedalaman seperti di Pasirah yang tidak terlalu berpengaruh, tetapi malahan memanfaatkan keadaan tersebut dengan menggeser peran perusahaan-perusahaan Eropa. Yakni, dengan mengandalkan hubungan sesama etnis Tionghoa di Singapura/Chinese Remiller, dalam berdagang karet. Serta, hubungan antar sesama etnis Tionghoa ini, dijalankan yang bersifat kekeluargaan dengan kepedulian untuk saling membantu, seperti dalam organisasi Tiong Hoa Hwee (Husin \& Maharihandono, 2020, pp. 159-160). Hal ini, seperti yang disampaikan oleh Tandelilin dalam (Elvinawanty et al., 2020, p. 176), kalau yang terkandung dalam ajaran Konfusianisme pada etnis Tionghoa, merupakan makna solidaritas kekeluargaan atau guanxi. Ada pun, dengan negeri asalnya yang juga patut diperhitungkan dalam perekonomian dunia. Pertumbuhan ekonomi China memang menjadi perhatian dunia, hal tersebut tidak dapat dilepaskan dari penerapan Sosialisme Pasar yang memiliki karakteristik China yang merupakan hasil pemikiran dari Bapak Reformasi China, yakni Deng Xiaoping. Kemajuan ekonomi pasar China yang di dalamnya menerapkan Sosialisme Pasar tidak hanya memberikan implikasi perekonomian China saja, tetapi juga berimplikasi kepada bidang lainnya (Lubis, 2018). Berdasarkan, sumber Biro Statistik Nasional China pertumbuhan ekonomi China di dunia berada di atas $6,7 \%$.

Orang-orang etnis China sendiri telah bertalian dengan Nusantara, diperkirakan sudah sejak lama, yaitu sekitar $3 \mathrm{M}$ dan $4 \mathrm{M}$. Namun, bukti yang kuat menunjukkan pada abad $5 \mathrm{M}$, berdasarkan catatan pelayaran Fa Hsien serta Gunavarman. Begitupun dengan pada masa sekarang. Di Indonesia keberadaan masyarakat Tionghoa memiliki hubungan yang erat dengan pemerintahan. Dikarenakan, campur tangan dari pemerintah sehingga mendominasi perekonomian di Indonesia. Kegiatan usaha di ekonomi kebanyakan dikuasai oleh masyarakat Tionghoa mengakibatkan hubungan kurang baik antara masyarakat pribumi dengan etnis Tionghoa (Amalia, 2015). Kegiatan usaha kecil menengah di Indonesia didominasi oleh masyarakat Tionghoa. Masyarakat Tionghoa, menjadi salah satu yang memiliki peran dalam perekonomian di Indonesia. Hal tersebut, memiliki pengaruh akibat beberapa faktor dari kebudayaan, pendidikan, sikap, keturunan dan orientasi. Misalnya saja, seperti apa yang diuraikan di dalam penelitian (Harahap, 2020, p. 227), yang menjelaskan kalau etnis Tionghoa sudah menyesuaikan kehidupan mereka di Palembang dengan cara berwirausaha atau berdagang, yang dilakukannya jauh sejak zaman kerajaan Sriwijaya bahkan sampai peralihan kesultanan Palembang, hingga pada masa sekarang mereka dapat melebur dengan pribumi.

Maka, dalam rangka melakukan penelitian ini, yang bertujuan untuk menganalisis sikap eklusivisme masyarakat etnis Tionghoa di Tangerang khususnya yang terdapat pada perdagangan di daerah Ciledug sebagai sebuah tindakan sosial, yang dikaji secara mendalam terutama mengenai bagaimana 
ajaran konfusianisme menjadi sebuah perilaku dagang yang ada pada karakter etnis Tionghoa yang tercerminkan melalui penguasaan ekonomi. Jelasnya, penelitian ini mempunyai fokus utama, yakni kajian sikap dalam ajaran Konfusianisme sebagai sebuah tindakan sosial dari etnis Tionghoa pada perdagangan di daerah Ciledug. Tujuan pada penelitian ini sangat penting untuk dikaji, yang akan bermanfaat dalam memahami tindakan sosial tentang pemikiran filosofis yang terkandung dalam ajaran Konfusianisme pada etnis Tionghoa yang ada di daerah Ciledug dengan kehidupan perekonomiannya, yang baik untuk ditiru oleh khalayak luas. Selain itu, untuk pembelajaran sebagai sebuah referensi dengan bagaimana bersikap dalam berwirausaha yang sebagaimana dapat dipelajari dari etnis Tionghoa pada perdagangan di daerah Ciledug.

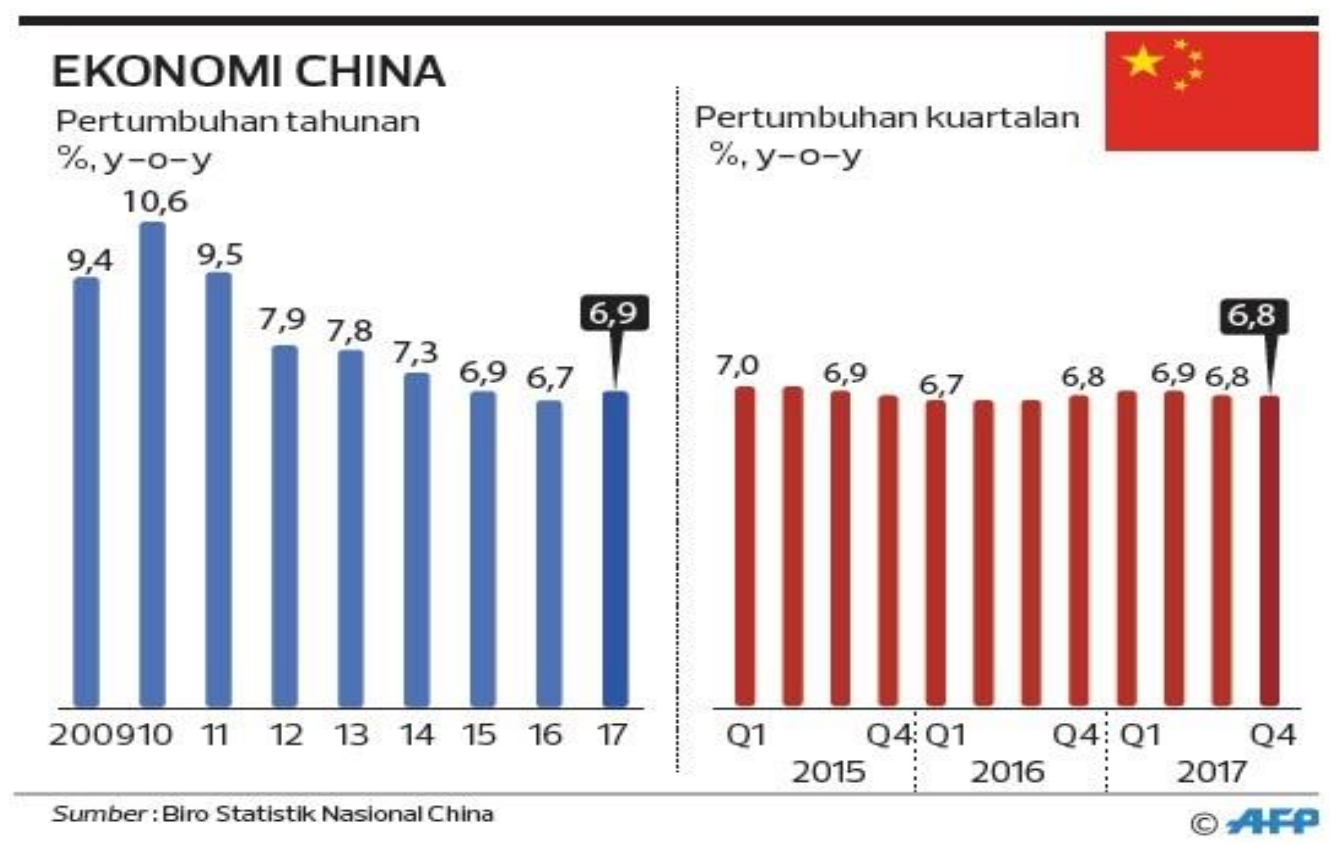

Gambar 1. Data Pertumbuhan Ekonomi China

\section{METODE}

Untuk melakukan penelitian ini, penulis melakukan dengan metode penelitian kualitatif, metode penelitian kualitatif merupakan suatu penelitian yang digunakan untuk meneliti suatu objek berdasarkan lingkungan alaminya, yang di dalamnya peneliti melakukan observasi langsung ke lapangan, dan peneliti melakukan observasi ke Plaza Baru Ciledug, penulis ingin meneliti terkait bagaimana sikap berdagang yang dilakukan oleh etnis Tionghoa di Ciledug dengan kata kunci melihat apakah diimplementasikan ajaran konfusianisme dalam berdagang. Maka dari itu, penulis melakukan observasi dalam menemukan data yang ilmiah. Berdasarkan, penelitian kualitatif, peneliti juga menggunakan pendekatan fenomenologi, menurut Collin (1997:111) fenomenologi mampu mengungkap sesuatu secara meyakinkan, meskipun objek itu merupakan suatu objek kognitif maupun tindakan ataupun ucapan. Karena, penelitian yang dilakukan adalah untuk meneliti sikap yang direprentasikan oleh etnis Tionghoa pada perdagangan di Plaza Baru Ciledug, maka penulis melakukannya dengan pendekatan fenomenologi. Untuk melakukan analisis data, penulis menggunakan metode Verstehen yang diperkenalkan oleh Max Weber, yakni memahami tindakan sosial secara interpretatif berdasarkan rasional, empatik, dan apresiatif (Damsar, 2017). Serta dianlisis dengan teori tindakan sosial yang diperkenalkan oleh Max Weber. Salah satunya, melalui pemahaman empatik yang kami gunakan dalam memaknai sikap yang ditunjukkan oleh masyarakat etnis Tionghoa di daerah Ciledug dalam menjalankan perniagaan.

\section{HASIL DAN PEMBAHASAN}

Hasil

Ajaran Konfusianisme, ajaran, yang terletak pada etika dan moral yang saling berhubungan antar manusia dengan statusnya. Di dalam ajaran moralnya konfusius, mengandung unsur-unsur sifat bijak manusia yang berpedoman pada sifat yang terpuji, jika ada kekacauan di masyarakat dapat diatasi, serta negara dapat kembali teratur dan tenteram. Konfusian, pada pemerintah agar penguasa bertindak 
berdasarkan pada kemanusian dan keadilan sehingga dicintai dan dipatuhi oleh rakyatnya. Dalam, ajaran Konfusius yang terletak pada moral sudah tertanamkan sejak kecil untuk menghormati orang yang lebih tua. Pada masa kecil ini menjadi dasar yang paling utama ketika sudah beranjak dewasa mempunyai moral yang baik sehingga tidak mudah hilang oleh sikap yang dapat merusak akhlak (Rosadi, 2015). Ajaran konfusianisme, terdapat lima sikap yang mengajarkan pada interaksi antar manusia dalam kehidupan bermasyarakat yaitu, pertama ren mengajarkan dituntut untuk saling mengasihi pada semua orang yang ada disekitar kita. Yang kedua Yi, mengajarkan jika bahwa moral, pengetauan tidak diajarkan, mengetahui kebenaran tetapi tidak melakukannya, mengetahui kekurangan tetapi tidak mengubah maka mengalami keraguan didalam dirinya. Ketiga $L i$, mengajarkan norma-norma seseorang dalam bersikap, yang berlaku di dalam kehidupan, contoh dalam suami istri, atasan dan bawahan, serta berkeluarga harus saling menghormati agar terhindar dari pertikaian. Keempat $Z h i$, mengajarkan bahwa orang yang bijaksana, harus bisa mempertimbangan dan berpikir panjang dengan baik atas segala kemungkinan yang terjadi, untuk mengambil keputusan yang boleh dilakukan dan yang tidak boleh dilakukan sehingga dapat menemukan solusi yang terbaik jika terjadimasalah. Kelima Sheng, mengajarkan manusia jika kita dapat masukan atau mendengarkan kebaikan kita harus mempratekannya dengan begitu kita bisa mencapai kesempurnaan akhlak dan menjadi suci . (Steffi Thanissa Halim, 2014; Amalia, 2015)

Pada zaman dinasti Qin Shi huang di tahun 221-207 SM, telah menerapkan pelarangan agar tidak menyebarkan pemikiran Konfusius dan membakar semua buku yang didalamnya terdapat pemikiran konfusius. Namun, dalam sejarah kedinastian yang ada di China ajaran konfusius mendapat banyak tempat terhormat dan mampu bertahan selama menghadapi persaingan dengan ajaran-ajaran agama atau falsafah kehidupan yang masuk di China. Pada tahun 1644-1912, bersamaan dengan runtuhnya sistem monarki di China ajaran konfusius mengalami kemunduran besar karena ajaran ini menjadi sasaran kritikan di zaman revolusi. Ajaran konfusianisme ini, menjadi tidak kelihatan setelah pemerintahan nasionalis tergusur ke Taiwan. Segala, yang berkaitan dengan feodal kapitalis ajaran konfusius dilarang pada saat Republik China berdiri di tahun 1949. Revolusi kebudayaan pada tahun 1966-1976, juga menjadi puncak penolakan konfusianisme berlangsung, menganggap pemikiran dan ajaran telah usang sehingga menghambat langkah lajunya revolusi sosialis China (Asruchin, 2018). Namun, ketika China sudah membuka diri ke dunia luar mengalami pertumbuhan ekonomi yang pesat, tetapi terdapat permasalahan pemerataan pendapatan dan ketimpangan sosial menjadi gangguan ketertiban di masyarakat. Untuk mengatasi masalah tersebut maka diperlukan adanya legitimasi dalam menghadapi persaingan di dunia global, masyarakat China kembali ke ajaran konfusius. Dengan begitu ajaran konfusius dapat membuat keseimbangan hidup, tingkah laku, keadilan serta hormat kepada orang tua diharapkan mampu mengembalikan ketentraman masyarakat. Konfusianisme ini sudah menjadi bagian dari masyarakat China dan sudah menjadi identitas bangsa Cina yang terkenal hingga seluruh dunia dan internasional. Pemerintah Cina ini membentuk sebuah lembaga yang bernama Confucius Institue untuk mempromosikan bahasa dan budaya China di seluruh dunia. Pada tahun 2004 sejak diresmikannya Confucius Institute di Hanban yang merupakan kantor pengelolanya telah membuka 480 di berbagai dunia. Pada tahun 2020 terus bertambah jumlah menjadi 1000 buah, dari mulai pelajar atau mahasiswa yang berminat belajar bahasa mandarin mencapai 200 juta menggeser peminat bahasa Inggris. Di Indonesia sendiri sudah ada enam Confucius Institute.

Pada tahun sekarang, China mempunyai pertumbuhan perekonomian yang pesat. China tumbuh sebagai negara yang cepat sekali perkembangan ekonomi dalam bidang industri, investasi, perdagangan, maupun teknologi sehingga menciptakan pasar bebas yang dapat mengurangi kemiskinan warga negara China. Pada tahun sekarang telah menciptakan perkembangan-perkembangan kekayaan intelektual yang terjadi pada bidang apapaun. Masyarakat China, memperluas dan menciptakan intelektual dengan kreativitas dan inovasi untuk mendatangkan kemakmuran dan pertumbuhan ekonomi (Fabrin, 2018). Dalam, menjalankan kegiatan perekonomian pemerintah bekerjasama dengan pihak swasta dalam sistem ekonomi campuran. Dengan menggunakan sistem ekonomi campuran ini menambah perekonomian China, pemerintah berperan penting dalam pemerataan perekonomian yang dilakukan oleh rakyatnya secara bebas dalam memproduksi barang, adanya pengontrolan dari pemerintah China dengan legitimasi dan konstitusi. Selain sistem ekonomi campuran ada juga sistem ekonomi kapitalis untuk membebaskan rakyat China untuk bebas dalam berproduksi barang secara kreatif. Ekonomi campuran juga telah berkerjasama dengan kapitalis dan komunis, mengambil jenis yang berharga dari keduanya, serta dapat bersandar mau kearah komunis atau kearah kapitalisme walaupun dengan begitu ajaran konfusianisme tetap digunakan.

Dilihat dari fakta sejarahnya, bahwa etnis Tionghoa datang ke Indonesia sudah sangat lama. Kedatangan etnis ini tidak semata-mata hanya ingin berdagang, tetapi juga terdapat kepentingankepentingan lainnya, seperti penyebaran agama dan juga pengetahuan seperti sastra, dll. Etnis ini juga merupakan salah satu etnis yang leluhurnya berasal dari Tiongkok (Cina). Sekitar tahun 300 SM, terdapat bukti sejarah bahwa pedagang Tionghoa datang dari pesisir laut China Selatan. Pada catatan sejarah tertulis, bahwa pedagang-pedagang China merupakan pedagang lama yang telah datang ke Asia Tenggara. Awalnya, 
kedatangan mereka ke Asia Tenggara hanya untuk tinggal beberapa waktu saja, selama mereka berkunjung di beberapa Kota Pesisir. Sebenarnya bagaimana proses mereka menjadi penduduk Indonesia belum terdapat cerita yang pasti. Pada tahun 1619, sebelum Jayakarta dijajah oleh Belanda dibawah Pasukan Jan Pieterszoon Coen, orang Tionghoa telah menetap di wilayah Banten dan juga terdapat di tempat-tempat lain di luar Jawa. Pada masa penyerangan kompeni terhadap Jakarta, orang-orang Tonghoa ini di pekerjaankan sebagai perantara dalam pengaturan kapitulasi beberapa kalangan ningrat setempat kepada Belanda. Ketika masa jabatan Coen yang merupakan gubernur jenderal di Batavia, ia mengizinkan sekitar 350 orang Tionghoa untuk tinggal di dalam kota dan juga mereka dipekerjakan sebagai pedagang kecil. Pada saat itu, Coen menginginkan Batavia berkembang secepat mungkin sebagai kota perdagangan terbesar di Hindia Belanda. Maka dari itu, untuk mewujudkan cita-cita nya, Coen memberikan izin terhadap masyarakat Tinghoa untuk tinggal di Batavia dan bergerak dalam bidang perdagangan, industri dan pertanian. Maka dari itu, sebenarnya terdapat dua alasan yang mendorong kedatangan kaum Tionghoa ke Nusantara, yang pertama yaitu alasan ekonomi. Hal tersebut, telah membawa masyarakat Cina pada peningkatan angka kemiskinan, kerusuhan dan keresahan sosial. Kemudian diperburuk lagi karena adanya bencana alam, seperti banjir, kekeringan, wabah dan sebagainya (Syakur \& Faiq, 2020; Wensi \& Azeharie, 2020).

Selama akhir masa penjajah kolonial Belanda mengeluarkan kebijakan-kebijakan baru yang memutuskan gerak masyarakat Tionghoa di Indonesia. Pemerintah kolonial lewat Wijkenstelse membuat pemukiman khusus etnis Tionghoa di sejumlah kota besar di Indonesia orang indonesia menyebutnya sebagai kampung pecinaan. Pada saat itu, etnis Tionghoa di isolasi dengan penduduk pribumi. Dan juga, pemerintah kolonial Belanda memberlakukan Passentelsel yang mewajibkan etnis Tionghoa ketika ingin melakukan perjalanan agar meminta izin terlebih dahulu (Husin \& Maharihandono, 2020; Kristiono, 2018). Etnis Tionghoa yang ada di Indonesia pada masa kolonial Hindia-Belanda telah membantu sedikit pengaruh pada perjuangan rakyat Indonesia. Banyak yang menganggap bahwa hal tersebut memberikan keuntungan bagi mereka. Pada masa memperjuangkan kemerdekaan Indonesia, terdapat banyak partai-partai yang berisikan masyarakat Tionghoa. Lebih umumnya, partai tersebut lebih memperjuanganya kepentingan etnisnya dibandingkan dengan tanah airnya (Pratama, 2016). Indonesia merupakan Negara yang multikulturalisme. Bahkan, di Indonesia terdapat masyarakat-masyarakat non pribumi. Salah satunya, yaitu Etnis Tionghoa, etnis ini merupakan sekumpulan masyarakat yang terbesar di Indonesia, dan bahkan mereka berhasil dalam menguasai pasar-pasar di Indonesia. Hal tersebut dilatarbelakangi, karena etnis Tionghoa merupakan masyarakat yang sangat menghargai pekerjaan. Orang Tionghoa yang datang ke Indonesia pun pada umumnya merupakan seorang pedagang, petani nelayan, dan lainnya. Orang Tionghoa ini dalam melakukan perdagangan selalu memilih tempat-tempat yang strategis, salah satunya yaitu di Pasar. Sudah bukan rahasia lagi, bahwa golongan minoritas etnis Tionghoa dapat memegang peranan penting dalam kehidupan perekonomian Indonesia (Elvinawanty et al., 2020; Satya, 2016).

Dari hasil observasi partisipan, yang berlangsung sejak tanggal 1 juli 2021, sampai 9 juli 2021, analisis hasil pengamatan memberikan pengalaman-pengalaman pada kami mengenai sikap atau perilaku terhadap kehidupan perekonomiannya yang ditunjukkan oleh beberapa masyarakat etnis Tionghoa di Ciledug dan sekitarnya, yang berhasil kami temui adalah pengusaha atau perniagaan menengah. Salah satunya, pengusaha yang menjual bahan-bahan bangunan, informasi yang kami dapat dari seorang pembeli dan selalu membeli bahan-bahan bangunan di toko tersebut, yang menurut penulis, bahwa pemilik toko bahan-bahan bangunan, beliau sangat menghormati usahanya, untuk mendapat keuntungan beliau tidak terlalu mengambil keuntungan terlalu banyak, walaupun begitu beliau sangat menjalani usahanya dengan sepenuh hati, dampaknya banyak orang-orang yang menjadi langganannya. Dan, untuk beberapa pengusaha lainnya di daerah Plaza Baru Ciledug, kebanyakan diantaranya mempunyai toko-toko emas dan elektronik handphone, walaupun demikian keberadaan mereka tidak dominan sebab di sana juga terdapat banyak toko-toko emas dan toko-toko Handphone dari orang-orang pribumi yang saling bertetangga. Dari, hasil observasi yang kami lakukan, dalam beberapa rentang waktu kami memahami jika pemahaman mereka tentang Konfusianisme tidak terlalu mengenal ajaran yang diajarkan Konfusius, sebab mereka hanya sekadar tahu, namun demikian, secara tidak sadar perilaku berdagang pada sebagian etnis Tionghoa yang berada di daerah Ciledug dan sekitarnya, sebenarnya mencerminkan dari ajaran Konfusius, yakni kehidupan mereka yang cenderung sederhana dari orientasi mereka dalam berdagang yang tidak terlalu ambisius dalam mendapatkan keuntungan yang tinggi dan tetap menghargai usaha yang mereka kerjakan dengan sepenuh hati dengan menjaga kualitas barang. Sehingga, berdampak pada kepercayaan konsumen, dan hubungan tersebut dijaga dengan baik di dalam perniagaan yang mereka jalani. Pernyataan tersebut, didukung oleh pendapat, yang menyatakan bahwa selain perilaku untuk etos kerja tinggi, tidak berlebihan atau berhemat, menyisihkan penghasilan, optimis juga menekankan pada menjaga hubungan atau kepercayaan yang berkaitan dengan identitas yang itulah sebagai dasar yang kuat, serta menjadi etika atau 
tradisi yang terkoneksi dalam makna filosofi Konfusianisme sehingga lekat dengan budaya Tionghoa, yang telah dididik sejak dini (Qibtiyah, 2019; Wensi \& Azeharie, 2020).

Maka dari itu, meskipun para pedagang etnis Tionghoa yang terdapat di Plaza Ciledug terlihat tidak begitu paham dengan ajaran konfusianisme, tetapi mereka sudah mencerminkan cara berdagang dengan mengikuti ajaran konsfusianisme, seperti menghargai pekerjaan. Konfusius berhasil mengubah pandangan masyarakat, dimana dikatakan bahwa manusia berprilaku mulia, tidak memikirkan diri sendiri, adil dan ramah maka ia memiliki kesempatan dan juga bisa mendapatkan Chun Tzu. Chun Tzu merupakan istilah yang ditujukkan untuk orang yang memiliki keturunan baik. Jika dilihat dari cara berdagang yang dilakukan oleh etnis Tionghoa di Plaza Ciledug terlihat bahwa mereka tidak mementingkan diri sendiri, toko yang mereka miliki ramai pengunjung karena mereka bekerja dengan tidak mengambil keuntungan yang besar, terlihat disitulah moral yang dimiliki oleh etnis Tionghoa. Hingga, sekarang pun ajaran Konfusianisme yang melekat pada diri masyarakatnya masih dimiliki oleh etnis Tionghoa di Plaza Ciledug (Amalia, 2015; Rahayu \& Indiarti, 2020).

Pemahaman mengenai perilaku atau sikap yang ditunjukkan oleh pengusaha etnis Tionghoa di daerah Ciledug, kami memakai analisis interpretasi tindakan sosial Max Weber, setidaknya ada empat cara, yaitu rasional, empatik, dan apresiatif. Untuk memahaminya kami mengintepretasikan dengan menempatkan pemamahan perilaku perekonomian para pengusaha dari etnis Tionghoa pada pemikiranya yang melibatkan keadaan emosional eksternal, yakni sikap tersebut memang tidak secara langsung sesuai dengan ajaran Konfusianisme atau secara tidak sadar mereka mengimplementasikannya, sebab perilaku atau sikap yang ditunjukkan dalam perniagaan sudah menjadi tradisi yang telah dilakukan dari keluarga atau komunitas etnis Tionghoa, yang dengan itu mereka pertahankan agar bisa beradaptasi dengan lingkungan sekitar sebagai masyarakat minoritas, terutama dalam menjalankan usahanya mereka harus memiliki kemandirian melalui sikapnya yang tidak meremehkan pekerjaan, menjaga tindakan yang memungkinkan berpotensi pada konflik sosial. Dengan interpretasi tersebut, maka jelas dalam memahami tindakan sosial sebagai karakteristik etnis Tionghoa di Tangerang, melalui menilik perdagangan di daerah Ciledug, berdasarkan teori tindakan sosial yang diungkapkan oleh Max Weber, yang menjelaskan untuk dapat dibandingkan struktur dari lapisan-lapisan masyarakat dalam menelaah sebab masyarakat itu melakukan tindakan tersebut, peristiwa-peristiwa sejarah yang sesuai urutannya yang memberikan pengaruh terhadap sikap mereka, serta mengenal tindakan individu yang terkini, walaupun tidak dapat melakukan generalisasi keseluruhan pada srtuktur sosial (Elvinawanty et al., 2020; Jones, Pip, 2016). Yang demikian dari hasil penelusuran dan dianalisis penulis, dapat memahami bahwa tindakan sosial yang terdapat pada etnis Tionghoa di Tangerang dengan penguasaan perekonomian di daerah Ciledug, berdasarkan analisis teori tindakan sosial dalam tipe yang diklasifikasi oleh Max Weber, sebagai tindakan tradisional.

\section{SIMPULAN}

Di Indonesia dengan negara yang multikultural terdapat masyarakat dari pribumi ataupun non pribumi, non pribuminya adalah Etnis Tionghoa, etnis ini berhasil menguasai pasar-pasar dan menjadi sekumpulan masyarakat terbesar di Indonesia. Perilaku atau sikap yang ditunjukkan oleh pengusaha etnis Tionghoa di daerah Ciledug, yakni sikap tersebut memang tidak secara langsung sesuai dengan ajaran Konfusianisme atau secara tidak sadar mereka mengimplementasikannya, sebab perilaku atau sikap yang ditunjukkan dalam perniagaan sudah menjadi tradisi yang telah dilakukan dari keluarga atau komunitas etnis Tionghoa, yang dengan itu mereka pertahankan agar bisa beradaptasi dengan lingkungan sekitar sebagai masyarakat minoritas, terutama dalam menjalankan usahanya mereka harus memiliki kemandirian melalui sikapnya yang tidak meremehkan pekerjaan, menjaga tindakan yang memungkinkan berpotensi pada konflik sosial.

\section{DAFTAR PUSTAKA}

Amalia, F. (2015). Etos Budaya Kerja Pedagang Etnis Tionghoa di Pasar Semawis Semarang. Solidarity: Journal of Education, Society and Culture, 4(1). https://journal.unnes.ac.id/sju/index.php/solidarity/article/view/6041.

Apria, N. P., \& Mutia, A. (2018). Persepsi Dan Prilaku Pedagang Etnik Tionghoa Terhadap Bank Syariah Di Kota Jambi. Syari'ah: Jurnal Ekonomi Syari'ah, 6(1). https://doi.org/10.15575/syh.v6i1.196.

Damsar. (2017). Pengantar Teori Sosiologi. Kencana.

Elvinawanty, R., Yusnita, L., Rania, V., Silaban, L. B., \& Sembiring, W. C. (2020). Makna Kewirausahaan Pada Etnis Melayu, Etnis Jawa, Etnis Tionghoa, dan Etnis India di Kota Medan. Jurnal Penelitian Pendidikan, Psikologi Dan Kesehatan (J-P3K), 1(3), 174-181. https://doi.org/10.51849/j- 
p3k.v1i3.38.

Harahap, N. (2020). Adaptasi Berbasis Budaya dan Sosial Masyarakat (Studi Kasus Etnis Tionghoa di Kota Palembang). JUPIIS: Jurnal Pendidikan Ilmu-Ilmu Sosial, 12(1), 220. https: //doi.org/10.24114/jupiis.v12i1.16031.

Husin, H., \& Maharihandono, M. I. D. (2020). Adaptasi kelompok etnis tionghoa palembang pada masa depresi ekonomi 1930an. Jurnal Pendidikan Sejarah, 4(1), 152-161. https://journal.lppmunindra.ac.id/index.php/alursejarah/article/view/7082.

Jones, Pip, L. B. and S. L. B. (2016). Pengantar Teori-Teori SosiaL (A. F. Saifuddin (ed.); Kedua). Yayasan Pustaka Obor Indonesia.

Kristiono, M. J. (2018). Dari Tionghoa ke Tjina: Telaah Sejarah terhadap Demonisasi Etnis Tionghoa di Indonesia [From Tionghoa to China: A Historical Review of the Demonization of Chinese Ethnicity in Indonesia]. Verity: Jurnal Ilmiah Hubungan Internasional (International Relations Journal), 10(19), 34. https://doi.org/10.19166/verity.v10i19.1309.

Prasetyo, A. S., Fatimah, T., \& Padawangi, R. (2017). Perkembangan Kota Lama Tangerang Dan Potensinya Sebagai Destinasi Wisata Pusaka. Jurnal Arsitektur, Bangunan, \& Lingkungan, 7(1), 17-30.

Pratama, A. (2016). Partisipasi politik etnis Tionghoa di Indonesia. JIPP (Journal Ilmu Politik \& Pemerintahan), 2(2), 214-229. http://jurnal.unsil.ac.id/index.php/jipp/article/view/ADHKPRTM.

Qibtiyah, M. (2019). Tingkah Laku Ekonomi-Politik dalam Hegemoni Agama dan Budaya. Jurnal Studi Sosial Dan Politik, 3(1), 55-68. https://doi.org/10.19109/jssp.v3i1.4068.

Rahayu, P. P., \& Indiarti, P. T. (2020). Makna Peruntungan Usaha dalam Simbol di Budaya Imlek bagi Masyarakat Etnis Tionghoa Surabaya. Jurnal Psikologi Perseptual, 5(1). https://doi.org/10.24176/perseptual.v5i1.4980.

Satya, M. S. (2016). Strategi Masyarakat Etnis Tionghoa Dan Melayu Bangka Dalam Membangun Interaksi Sosial Untuk Memperkuat Kesatuan Bangsa. Jurnal Pendidikan Ilmu Sosial, 25(1), 110 - 23. https://doi.org/10.17509/jpis.v25i1.3667.

Syakur, M., \& Faiq, M. (2020). Reaktualisasi Khasanah Kewirausahaan Perspektif Tionghoa Muslim. Jurnal PROGRESS: Wahana Kreativitas Dan https: //doi.org/10.31942/pgrs.v8i2.3960.

Wensi, W., \& Azeharie, S. S. (2020). Interaksi Sosial antara Kelompok Masyarakat Dayak dan Kelompok $\begin{array}{llll}\text { Masyarakat Tionghoa di Singkawang. } & \text { Koneksi, }\end{array}$ https: //doi.org/10.24912/kn.v4i1.6613.

Yudha, A. A. N. B. K. (2020). Langkah cinta penuh derita etnis Tionghoa di Indonesia. SENADA (Seminar Nasional Desain Dan Arsitektur), 3, 47-56. 